\title{
Effect of Olive Leaves Extract on Alloxan Induced Diabetes in Male Albino Mice
}

\author{
Lekaa K. Al-Hayaly ${ }^{1}$, Alaa G. Al-Sultan², Saffa M. Sultan ${ }^{3}$ \\ \{Rahmaswe90@gmail.com¹, alaaghanim2a@gmail², Safaahawija@gmail.com³ \\ ${ }^{1}$ Collage of Medicine, University of Mosul, \\ ${ }^{2,3}$ Technical Institute/ Mosul, Northern Technical University
}

\begin{abstract}
The current study was aimed to evaluate the effect of olive leaves extract (OLE) on alloxan-induced diabetic male mice. The experimental mice were divided into five groups. mice of the first group were considered as normal controls. mice of the 2nd group were diabetic control. The $3^{\text {rd }}, 4^{\text {th, }}$ and $5^{\text {th }}$ groups were diabetic mice, treated with a daily oral dose of OLE (100 mg/kg) for one, two, and three weeks respectively. According to the biochemical observations, the levels of serum glucose, urea, and creatine were significantly increased parallel with detectable histopathological sections in kidney tissues of mice. Furthermore, there was a significant decrease in serum glucose, urea, and creatine of diabetic group under treatment with OLE as a contrast to diabetic mice. Besides, histological findings appeared improved renal architecture as reflected by reduced glomerular and return of Bowman's capsule to nearly normal structure in mice when compared with the control group. Collectively, Oral administration of aqueous olive leaf extracts to diabetic mice proven that the protective effects of OLE are referred to the antioxidant activities and active constituents of olive leaves extract.
\end{abstract}

\section{Introduction}

Diabetes is a chronic disease that occurs when the pancreas cannot produce enough insulin, or when the body is unable to effectively use the insulin it produces. On the other hand, the deficiency of insulin secretion and the shortage of beta cells in the pancreas will lead to high sugar levels in the blood. High blood sugar or hyperglycemia is one of the common effects of uncontrolled diabetes and leads to severe damage to many organs, especially nerves and blood vessels Such as retinopathy, heart disease, liver, and renal failure. (Akinnuga et al., 2010; Sebbagh et al., 2009 and Reid, 2006). High blood sugar in the long term promotes generic oxidative stress, retinopathy, foot damage, hearing impairment, and skin conditions(bacterial and fungal infections). (El-Serag et al., 2004 and El-Serag and Everhart, 2002).According to most studies, diabetes mellitus is an important factor for hepatopathy, Liver disease is a lifethreatening factor for people who suffer from diabetes.( de Marco et al., 1999). D M, Is the prime malady of renal defeat at current goes to disorder vascular (Heart failure, strokes, and circumferential vascular diseases) (Umar et al., 2010). Diabetic retinopathy is an important cause of blindness as a result of the prolonged accumulation of damage in the small capillary vessels (Brownlee, 2005a; Wolf, 2004). In addition, free radicals increased liver disease and eventually damaged hepatocytes, leading to liver fibrosis (Novo and Parola, 2008; Albano, 2006). Currently, insulin and oral therapies are the most common treatment for DM(Rendell, 
2004). Around $35 \%$ of Type 2 diabetics patients use alternatives therapeutic to control diabetes mellitus (Yeh et al., 2003). Recently, many popular herbs have been used to treat diabetes. remedy made from plants is less harmful than drugs made from chemicals material(Ghorbani,2013). These traditional plants have used an antihyperglycemic by improving insulin secretion in the cells of the pancreas and increasing the response of cell receptors to insulin, which leads to the regulation of blood sugar levels (Hongxiang et al.,2009). There are approximately $85 \%$ of the population of developing countries use herbal remedies to this day (Liu YN et al 2014). Olive leaves (O. Europaea) used in various civilizations over time as food and medicine because of its great benefits (Abd El-Rahman, 2016). Previous studies of olive leaves extract have proved effective recovery from health problems such as high insulin, high cholesterol, and liver fat (Sarbishegi et al.,2017and Nan et al., 2014 ). Hence, Given the importance of olive leaves and their important elements, this study was conducted to find out the effect of olive leaf extract on blood variables and histological changes in the kidney in diabetes all mice with nic mice.

\section{Material and method}

The study was conducted on a male mic obtained from the Technical College in Kirkuk. The animals were selected at the age of (2-3) months, their mean weight (27) gm, and healthy. The mice are placed in plastic cages with appropriate conditions of temperature $\left(25 \pm 1^{\circ} \mathrm{C}\right)$ and $(14$ hs, 10 hs light and dark) as well as ventilation. Animals were also given a special diet and water.

\section{Experimental design}

The mice were randomly distributed, using (25) male adult mice, we divided the mice into 5 groups, including the control group (5mice per group) and caged separately:

1. Group 1 (untreated control).

2. Group 2 mice have received alloxan (i.p.injection).

3. Group 3 Alloxan diabetic mic.e supplemented orally with olive leaf extract for one week.

4. Group 4 Alloxan diabetic mice supplemented orally with olive leaf extract for two weeks.

5. Group 5 Alloxan diabetic mice supplemented orally with olive leaf extract for three weeks.

\section{Induction of DM}

The animals were starved for 12 hours, and then experimental diabetes was introduced by subcutaneous injection with alloxan (British company BHD) at a dose of $(0.1 \mathrm{~g} / \mathrm{kg}$ of body weight) by dissolving $1 \mathrm{~g}$ of alloxan in $10 \mathrm{ml}$ of normal saline currently prepared, as for control animals, they were injected with $1 \mathrm{ml}$ of normal saline and given water and food normally (Raju et al., 2012). Animals with a glucose level greater than $200 \mathrm{mg} / 100 \mathrm{ml}$ were considered diabetic. 


\section{Plant Material and Extraction}

Olive leaves were cut in the autumn from the Technical College in Kirkuk by scissors and washed to get rid of dust and plankton and dried by leaving it in the shade at a temperature (25$30^{\circ} \mathrm{C}$ ) with a stream of dry air being passed in the room naturally for a week with continuous monitoring daily to prevent the occurrence of rot. The method of preparation described by (AlAttar \& Abu Zeid, 2013). Then the olive leaves were powdered and mixing with $160 \mathrm{ml}$ of distilled water in a $(4: 1)$ ratio. Then put the mixture in the blender for 5 minutes for intermittent periods. Thereafter mix the solutions of olive leaves by electric shaker type (Gesellschaft fur labortechnik- Germany) for two hours to obtain a homogeneous mixture then it was stored in a refrigerator at $\left(4{ }^{\circ} \mathrm{C}\right.$ for 24 hours). Finally, the mixture was filtered through several layers of gauze and centrifuged at a constant speed for a constant period of $3000 \mathrm{r} / 10 \mathrm{~m}$. The filtration was completed again by the Buchenger funnel using filter paper via a sliding van rotary vacuum pump. Thus, the pure water extract of olive leaves was frozen at $-20{ }^{\circ} \mathrm{C}$ and lyophilized at -50 ${ }^{\circ} \mathrm{C}$ under vacuum for $48 \mathrm{~h}$. the dried pure extracts were kept in frozen in plastic containers until the need to use.

\section{Bodyweight changes}

At the beginning of the experiment, the weights of the experimental mice were measured, as well as before the rat dissection process was performed at the end of each experiment by electronic balance. In addition to recording all clinical changes that appear on laboratory animals during the experiment period (Al-Attar and Zari, 2010).

\section{Biochemical estimation}

Blood samples were collected in special laboratory tubes at the end of each first, second, and third week respectively from fasting mice. After that the blood samples were separated by centrifuge for 15 minutes.

\section{Histological examination and microscopic photography}

Laboratory animals were dissected, the kidneys extracted and treated with histological preparations according to (Humason, 1979). The microscopic examination of the tissue sections was executed by using optical microscope type (Leitz Watzler, Germany fitted with a digital camera, Sony-DSC W30)

\section{Results}

Fig. $1 \mathrm{~A}-\mathrm{C}$ shows blood variables in the experimental groups of (glucose, urea, and creatinine). Where an increase is observed in the levels of serum glucose $(96 \mathrm{mg} / 100 \mathrm{ml})$, urea 
(30 $\mathrm{mg} / 100 \mathrm{ml})$, and creatinine $(0.97 \mathrm{mg} / 100 \mathrm{ml})$ in diabetic mice (group2) compared with normal control rats. Very slight changes were recorded in the serum of glucose, urea, and creatinine in

diabetic mice treated with oil leaf extract for one week (group3). While the results of the group treated with the extract for two weeks(group4) showed a marked decrease in the level of glucose $(145 \mathrm{mg} / 100 \mathrm{ml})$, urea $(43.7 \mathrm{mg} / 100 \mathrm{ml})$, and creatinine $(1.25 \mathrm{mg} / 100 \mathrm{ml})$ in diabetic mice as compared with the control group. The greatest decreased was seen in serum (group 5) glucose $(110 \mathrm{mg} / 100 \mathrm{ml})$, urea $(35.7 \mathrm{mg} / 100 \mathrm{ml})$, and creatinine $(1 \mathrm{mg} / 100 \mathrm{ml})$ as compared with (group 1) but not reach to a normal level as in control group.

Examination of tissue sections of the kidney of untreated mice appeared of any histological changes, and they were represented by normal structure and the renal glomeruli of Bowmans space showed no histopathological alterations (fig.2a). The sections of diabetic kidney for (group 2) appeared many alterations represented by an Increase in renal glomeruli size and dilation in Bowman's capsule. As well, the swelling in the blood vessels of the kidney and overcrowding of bleeding RBCs occur frequently showed in(fig.2b). While in groups 2 and 3 respectively showed slight Improvement and signs of tissue repair in renal glomeruli size and dilation in Bowman's capsule (fig.2c,d).In group5 treated with oil leaf extract for three weeks, kidney section elucidates the improvement of the histological changes represented by the number of renal glomeruli and the return of Bowman's capsule to nearly normal structure .where observed pyknosis, karyopyknosis nuclei and vacuolated in some tissue that lining s tubules (fig.2e).
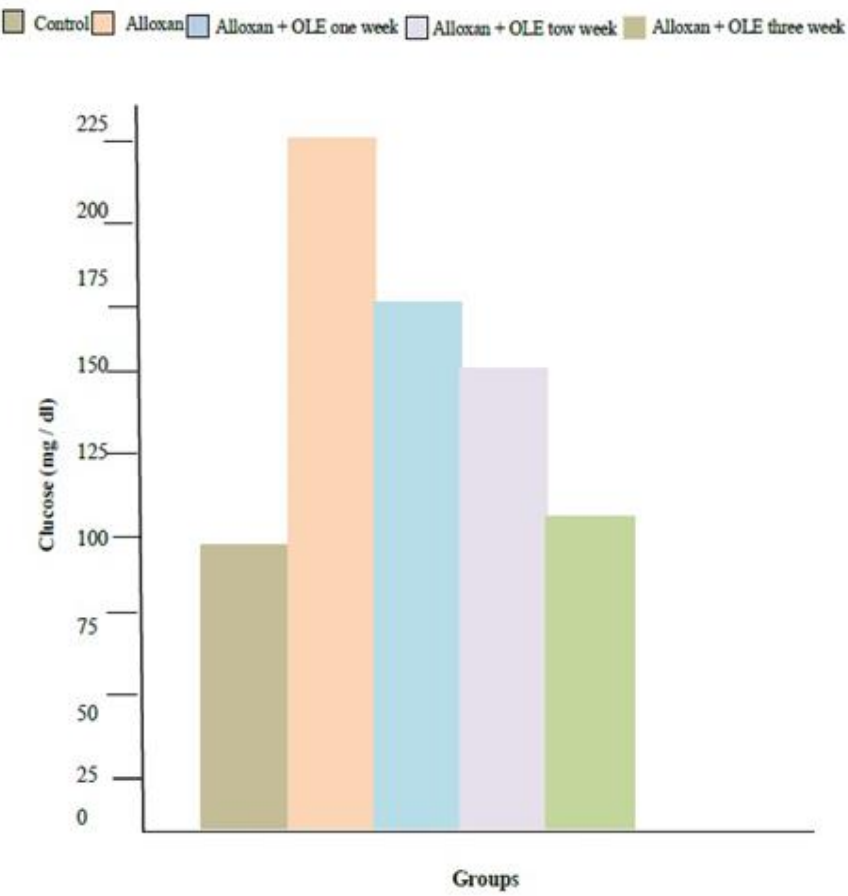
$\square$ Control $\square$ Alloxan $\square$ Alloxan + OLE one week $\square$ Alloxan + OLE tow week $\square$ Alloxan + OLE three week

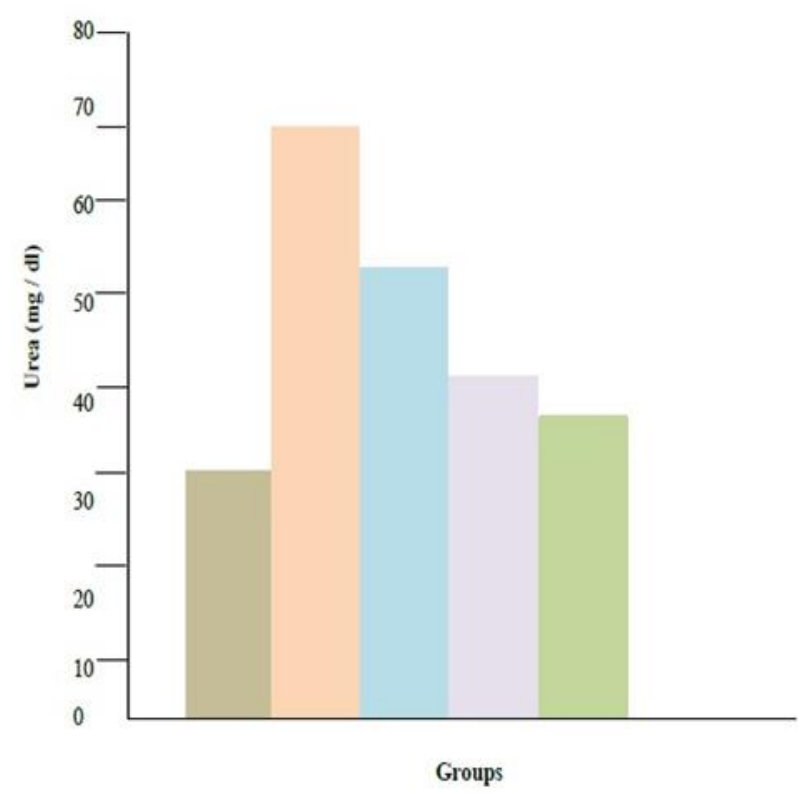

$\square$ Control $\square$ Alloxan $\square$ Alloxan + OLE one week $\square$ Alloxan + OLE tow week $\square$ Alloxan + OLE three week

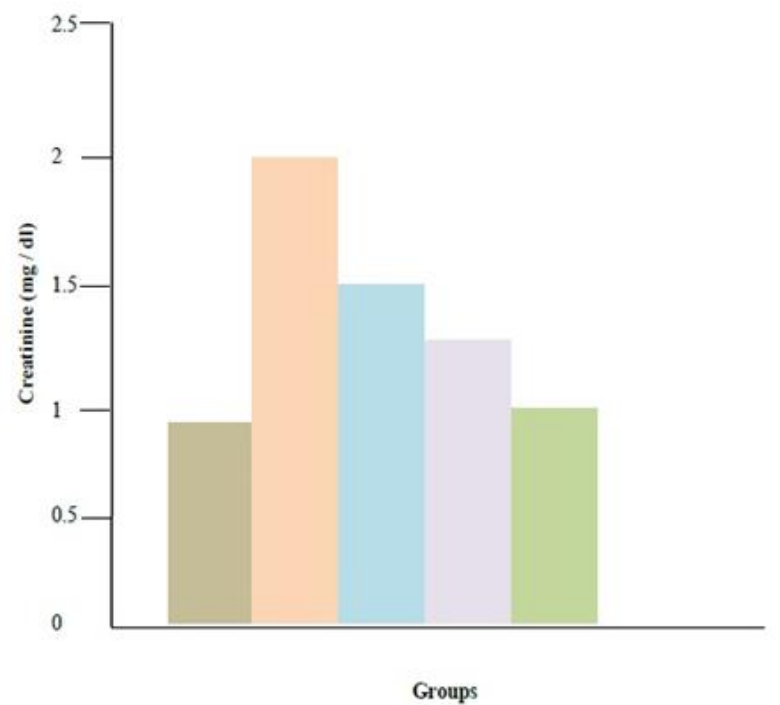

Fig.1. (A-C) Show levels of serum glucose (A), urea (B), and creatinine (C) from control, alloxan, alloxan, and OLE for one week, alloxan plus OLE for two weeks, alloxan plus OLE for three weeks in mice serum. 

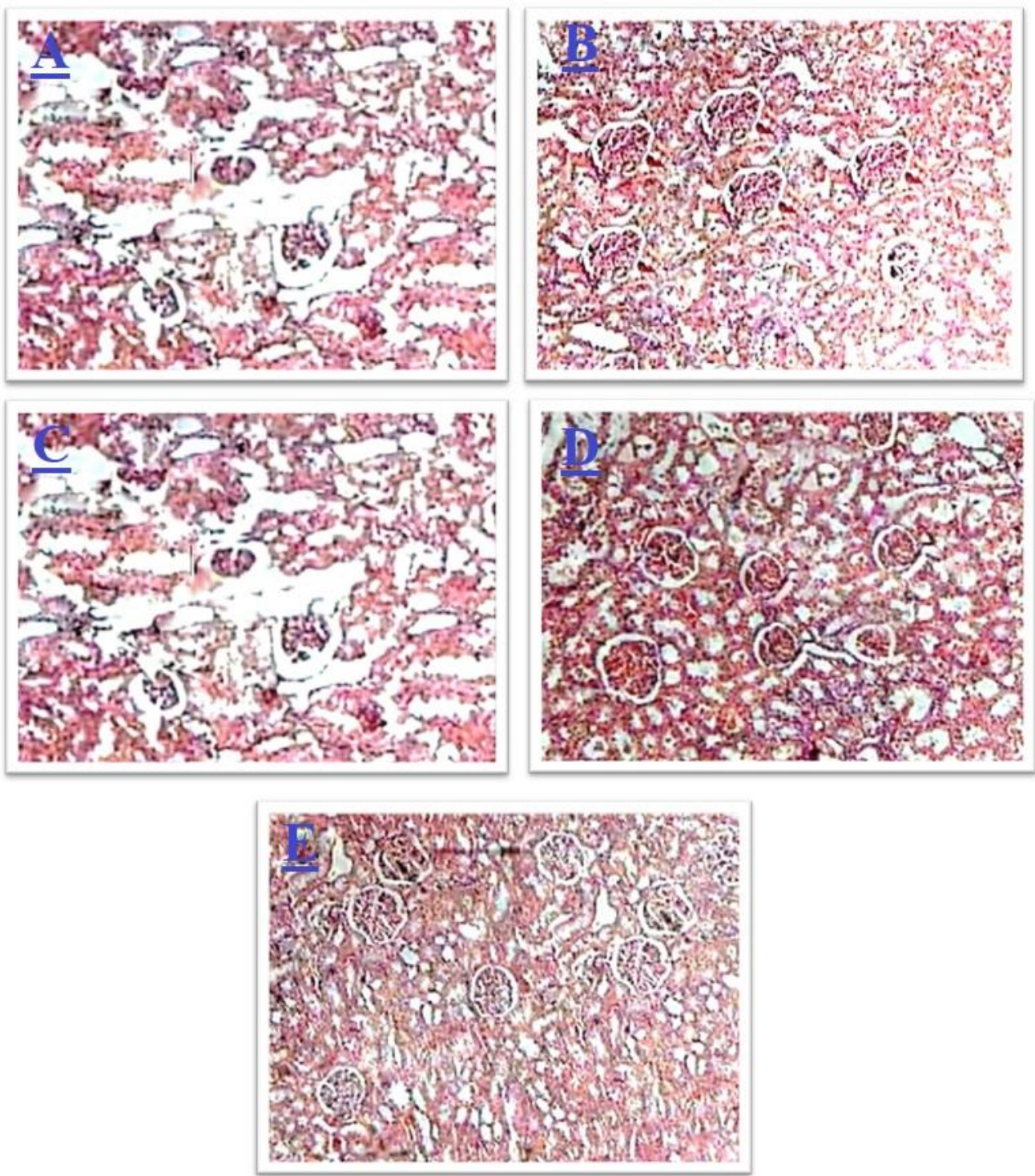

Fig.2. (A-E) Show a micrograph of kidney sections in all groups stained with H\&E stain,115X.(A) Control, (B) Alloxan, (C) Alloxan plus OLEfor one week, (D) Alloxan plus OLE for two weeks and (E) Alloxan plus OLE for three weeks treated mice.

\section{Discussions}

Diabetes mellitus is an inveterate situation that increased essentially in developing countries. Because of the importance of this disease and its affects a large segment of people in the big age who are suffering from obesity has been shed light on how the treatment of this 
disease. (Whiting et al., 2011). Alloxan was given attacks the beta cells in the pancreas and works to produce large quantities of free radicals that accumulate and be toxic and destroy beta cells that produce insulin, and it also increases the resistance of insulin cell receptors and thus stops the absorption of glucose by the cells and activates the process of glycolysis and gluconeogenesis (Szkudelski T. 2001). This leads to an increase in the accumulation of triglycerides and cholesterol and reduces the protein content of cells as a result of increasing the level of glucose in the blood (Dhanabal et al,2007). Studies have proven in recent years that treatment with medicinal plants has an effective impact in controlling high blood glucose levels and its complications (Marles and Farnsworth,1995) \&( Grover et al 2001). Among the various plants in nature, the olive tree was distinguished by unique characteristics. It has a special place throughout civilizations. Olea europaea was used as a raw extract of olive leaves in many studies for its superior ability to kill a large number of forms of bacteria and viruses in addition to reducing the level of blood glucose and blood pressure (El and Karakaya,2009). This study showed that i.p. injection of alloxan $100 \mathrm{mg} / \mathrm{kg} / \mathrm{B}$.W. caused significant high blood sugar and the development of experimental diabetes in mice after dosing, This rise is due to the ability of alloxan to attack beta cells in the pancreas and break down as a result of the accumulation of free radicals and thus leads to the discontinuation of insulin secretion(Stanely,etal2004).As well as, the levels of glucose, ureia, and creatinine in blood serum were observed significantly higher in group 2. These results are generally consistent with the results of other research conducted on the effect of alloxan (Zhang etal2016, al-sultan,2015). While in G3, G4 and G5 showed amelioration in serum level (glucose, urea, and creatinine) but not reach to normal level as in the control group. These results showed a decrease in the level of blood glucose as a result of presence of Olea europaea in OLE as it works to increase the absorption of glucose by the cells of the body or by improving $\beta$-cells and thus the production of insulin (Eidi, et al., 2009). Moreover OLE also contributes to preventing the action of the amylase enzyme found in the pancreatic and salivary juices and thus leads to a hypoglycemic as a result of the failure to digest and absorb the starch (Wainstein et al.,2012). It was also observed in the experiment conducted by (Omar,2010) on animals with diabetes, a decrease in the level of glucose and blood pressure by using olive leaf extract. The rise in parameter values of glucose, urea, and creatinine in our current study is consistent with many experimental studies on laboratory animals with diabetes (Salahuddin, et al 2010). The reason for the increase in urea and creatinine levels in the blood of animals with diabetes may be due to increased metabolism of liver proteins and plasma, also, to inhibit of the body ability to get rid of the products of protein metabolism (Hassan et al., 2009). On the other hand, the results of treatment with olive leaf extract for animals exposed to alloxan showed a marked decrease in the levels of glucose, urea, and creatinine compared with diabetic animals without treatment. The reason for the decrease in blood serums from (glucose, urea and creatinine) may be due to the improvement of the kidney filtration process as a result of renal glomerular regeneration (Mohammedetal.2018). And since the compounds of flavonoids are rich in antioxidants or inhibitors of free radicals that lead to nephroprotective (Helal, tal 2013). As well as, when treatment diabetic mice by using olive leaf extracts and their fruits led to a decrease in the serum of creatinine, uric acid, and urea (Laaboudi, et al. 2016). Furthermore, the biochemical results recorded in our current experiment may be caused by damage to the kidney and confirmed by histopathological changes that were observed in alloxan diabetic male mice. Accordingly, the results of histological examination of the group treated with alloxan showed many pathological tissue changes represented by congestion, inflammatory tissue, and shrinked glomeruli tuft with mesangial cell proliferation. These results were in agreement with (Mohammed et al. (2018); Hebi, Farid, Ajebli, \& Eddouks, 2017; Alsultan.2015) . Also, hyperglycemia leads to oxidative stress, which in turn causes renal tubular 
degeneration that has been observed in our experience. (Baynes, 1991). In addition, free radicals play an important role in the occurrence and growth of DM (Bindhumol, Chitra, \& Mathur, 2003).And so on, we noticed somewhat varying degrees of improvement in histopathological changes in the kidney due to the use of olive leaf extract in diabetic animals, This result is consistent with (Mohammed et al.(2018); Tavafi et al.(2012). Also, (Al-Attar and Alsalmi,2019) proposed the probable therapeutic use of olive leaf extract as a new nephroprotective factor against sever renal failure. As it is known that one of the important causes of cardiovascular disease and the end stage of kidney disease is the increased activation of the renin-angiotensin system(RAS) (Santos, Ferreira, \& Simões e Silva, 2008). Thus, glomerular filtration will change with the effect of arterial contractions in the renal tubules due to the presence of (Ang II) one of the important factors of (RAS) (Mizuiri, etal, 2008). In addition, an increase in Ang II leads to kidney fibrosis in patients with chronic kidney disease(Wen-lun,2016). Nevertheless, the therapeutic value of the olive leaf extract may be due to the ability of OLE to lower the Ang II in the kidney tissue and thus reduce the pressure on the arteries in the glomeruli of the kidneys (Scheffler, et al., 2008).over and above the antioxidant of actions of OLE cause to suppression of physiological and histopathological changes in diabetic mice. Consequently, it can be deduced that olive leaves extract has a useful effect on DM. Finally, further testing is needed to demonstrate the effectiveness of various concentrations and dosage of olive leaves extract and its ingredient as favorable therapeutic factors for diabetes mellitus and its complications

\section{Conclusion}

We can conclude that the olive leaves extract has an effective effect on alloxan-induced diabetes male mice by reducing the biochemical and histological changes due to the action of antioxidants. Finally, additional research must be done using different concentrations of the OLE for different periods.

\section{References}

[1] Akinnuga, A.M., Bamidele, O., Ebunlomo, O.A., Adeniyi, O.S., Adeleyea, G.S., Ebomuche, L.C.: Hypoglycaemic effects of dietary intake of ripe and unripe lycopersicon esculentum (tomatoes) on streptozotocin-induced diabetes mellitus in rats. J. Biol. Sci. Vol. 10, 50-53 (2010)

[2] Sebbagh, N., Cruciani-Guglielmacci, C., Ouali F, Berthault, M., Rouch, C., Chabane, D., Magnan C.: Comparative effects of Citrullus colocynthis,sunflower and olive oil-enriched diet in streptozotocin-induced diabetes in rats. Diabetes \& Metabolism, Vol. 35,178-184 (2009)

[3] Reid, A.E.: Non-alcoholic fatty liver disease.In: Feldman, M., Friedman, L.S.,Brandt, L.J. (Eds.), Sleisenger and Fordtran's Gastrointestinal and Liver Disease:Pathophysiology/diagnosis/management.eighth ed. Saunders, St. Louis,Missouri, USA, pp. 1772-1799 (2006)

[4] El-Serag, H.B., Everhart, J.E.: Diabetes increases the risk of acute hepatic failure. Gastroenterology 122, 1822-1828 (2002)

[5] El-Serag, H.B., Tran, T., Everhart, J.E.: Diabetes increases the risk of chronic liver disease and hepatocellular carcinoma. Gastroenterology 126, 460-468 (2004)

[6] de Marco, R., Locatelli, F., Zoppini, G., Verlato, G., Bonora, E., Muggeo, M.: Cause-specific mortality in type 2 diabetes: the verona diabetes study. Diabetes Care 22, 756-761 (1999) 
[7] Umar, A., Ahmed, Q.U., Muhammad, B.Y., Dogarai, B., Soad, S.Z.: Antihyperglycemic activity of the leaves of Tetracera scandens Linn, Merr (Dilleniaceae) in alloxan induced diabetic rats. J. Ethnopharmacol. Vol. 1,140-145 (2010)

[8] Wolf, G.: New insights into the pathophysiology of diabetic nephropathy:from haemodynamics to molecular pathology. Eur. J. Clin. Invest. 34, 785-796 (2004)

[9] Brownlee, M.: The pathobiology of diabetic complications: a unifying mechanism. Diabetes 54, 1615-1625 (2005)

[10] Albano, E.: Alcohol, oxidative stress and free radical damage. Proc. Nutr. Soc.65, 278-290 (2006)

[11] Novo, E., Parola, M.: Redox mechanisms in hepatic chronic wound healing and fibrogenesis. Fibrogenesis Tissue Repair ;1(1), 5, (2008)

[12] Hongxiang H, George T, Vay Liang G. VLW: Hypoglycemic herbs and their action mechanisms. Chin Med, Vol. 4,11-14 (2009)

[13] Ghorbani, A.: Best herbs for managing diabetes: A review of clinical studies'. J. Pharm. Sci. Vol. 49, 413-422 (2013)

[14] Liu YN, Jung JH, Park H, Kim H.: Olive leaf extract suppresses messenger RNA expression of proinflammatory cytokines and enhances insulin receptor substrate 1 expression in the rats with streptozotocin and highfat diet-induced diabetes. Nutr Res Vol. 34, 450-7 (2014)

[15] Nan JN, Ververis K, Bollu S, Rodd AL, Swarup O, et al. Biological effects of the olive polyphenol, hydroxytyrosol: An extra view from genomewide transcriptome analysis. Hell J Nucl Med Vol. 17, 62-9 (2014)

[16] Abd El-Rahman, H.S.M.: The effect of olive leaf extract and A-Tocopherol on nephroprotective activity in rats. J. Nutr. Food Sci, Vol. 6, 479 (2016)

[17] Sarbishegi, M., Gorgich, E.A.C., Khajavi, O.: Olive leaves extract improved sperm quality and antioxidant status in the testis of rat exposed to rotenone.Nephrourol Mon. 9, (3) e47127 (2017)

[18] Al-Attar, A.M., Zari, T.A.: Influences of crude extract of tea leaves, camellia sinensis, on streptozotocin diabetic male albino mice. Saudi J. Biol. Sci. Vol. 17, 295-301 (2010)

[19] Hummason, G.L.: Animal Tissue Techniques. $4^{\text {th }}$ ed. W.H. Freeman and company, USA, PP: 569-579 (1979)

[20] Whiting, D.R., Guariguata, L., Weil, C., Shaw, J.: IDF diabetes stlas: global estimates of the prevalence of diabetes for 2011 and 2030. Diabetes Res. Clin.Pract. 94, 311-321 (2011)

[21] Szkudelski T.: The mechanism of alloxan and streptozotocin action in B cell of the rat pancreas. Physiol Res. Vol. 50, 536-546 (2001)

[22] Dhanabal, S.P.;Raja, M.K.; Ramanathan, M.and Suresh, B.: Hypoglycemic activity of Nymphaca stellata leaves ethnolic extract in alloxan induced diabetic rats. Fitoterapia. Vol. 78: 288-291 (2007)

[23] El SN, Karakaya S.: Olive tree (Olea europaea) leaves: potential beneficial effects on human health. Nutr Rev, Vol. 67, 632-638 (2009)

[24] Stanely P, Kamalakkannan N, Venugopal P.: Antidiabetic and antihyperlipidemic effect of alcoholic Syzigium cumini seeds in alloxan induced diabetic albino rats. Journal of Ethnopharmacology 91:209-213 (2004)

[25] Zhang, Y., Feng, F., Chen, T., Li, Z., Shen, Q.W.: Antidiabetic and25 antihyperlipidemic activities of Forsythia suspensa (Thunb.) Vahl (fruit) in streptozotocin-induced diabetes mice. J. Ethnopharmacol.192, 256-263 (2016)

[26] Eidi A, Eidi M, Darzi R.: Antidiabetic effect of Oleaeuropaea L. in normal and diabetic rats. Phytother Res. Vol. 23, 347-50 (2009) 
[27] Wainstein J, Ganz T, Boaz M, Bar Dayan Y, Dolev E, Kerem Z, Madar Z.: Olive leaf extract as a hypoglycemic agent in both human diabetic subjects and in rats. J Med Food. 15(7):605-10 (2012)

[28] Omar, S. H.: Oleuropein in olive and its pharmacological effects. Scientia Pharmaceutica, 78, 133-154 (2010)

[29] Salahuddin, M., Jalalpure, S. S., \& Gadge, N. B.: Antidiabetic activity of aqueous bark extract of Cassia glauca in streptozotocin-induced diabetic rats.Canadian Journal of Physiology and Pharmacology, 88, 153-160 (2010)

[30] Hassan, H. A., El-Agmy, S. M., Gaur, R. L., Fernando, A., Raj, M., \& Ouhtit, A.: In vivo evidence of hepato-and reno-protective effect of garlic oil against sodium nitrite-induced oxidative stress. International Journal of Biological Sciences, 5, 249-255 (2009)

[31] Mohammed A. Hend, Hanan A. Okail, Mona A. Ibrahim3 and Nahed M. Emam.: Influences of olive leaf extract in the kidney of diabetic pregnant mice and their Offspring. The Journal of Basic and Applied Zoology, Vol. 79, 3 (2018)

[32] Laaboudi, W., Ghanam, J., Ghoumari, O., Sounni, F., Merzouki, M., \& Benlemlih, M. Hypoglycemic and hypolipidemic effects of phenolic olive tree extract in streptozotocin diabetic rats. International Journal of Pharmacy and Pharmaceutical Sciences, 8, 287-291(2016)

[33] Hebi, M., Farid, O., Ajebli, M., \& Eddouks, M.: Potent antihyperglycemic and hypoglycemic effect of Tamarix articulata Vahl. in normal and streptozotocininduced diabetic rats. Biomedicine \& Pharmacotherapy, 87, 230-239 (2017)

[34] AL-sultan, A.G.: The effect of Arabic Gum on the histopathological changes on diabetes mellitus experimentally induced in rats. Bas.J.Vet.Res.Vol.14, 158-177 (2015)

[35] Baynes, J. W.: Role of oxidative stress in development of complications in diabetes. Diabetes, 40, 405-412 (1991)

[36] Tavafi, M., Ahmadvand, H., \& Toolabi, P.: Inhibitory effect of olive leaf extract on gentamicin-induced nephrotoxicity in rats. Iranian Journal of Kidney Diseases, 6, 25 (2012)

[37] Al-Attar, A. M., \& Alsalmi, F. A. Effect of Olea europaea leaves extract on streptozotocin induced diabetes in male albino rats. Saudi Journal of Biological Sciences. 26,118-128 (2019)

[38] Scheffler, A., Rauwald, H., Kampa, B., Mann, U., Mohr, F., \& Dhein, S.: Olea europaea leaf extract exerts L-type Ca 2+ channel antagonistic effects. Journal of Ethnopharmacology, 120, 233-240 (2008)

[39] Al-Attar, A. M., \& Abu Zeid, I. M.: Effect of tea (Camellia sinensis) and olive (Olea europaea L.) leaves extracts on male mice exposed to diazinon. BioMed Research International, 2013, 6. Article ID 461415. https://doi.org/10.1155/2013/4614 (2013)

[40] Helal, E. G., El-Wahab, S. M. A., El Refaey, H., \& Mohammad, A. A.: Antidiabetic and antihyperlipidemic effect of Balanites aegyptiaca seeds (aqueous extract) on diabetic rats. Egyptian Journal of Hospital Medicine,52, 725-739 (2013)

[41] Santos, R. A., Ferreira, A. J., \& Simões e Silva, A. C.: Recent advances in theangiotensinconverting enzyme 2-angiotensin (1-7)-Mas axis. Experimental Physiology, 93, 519-527 (2008)

[42] Mizuiri, S., Hemmi, H., Arita, M., Ohashi, Y., Tanaka, Y., Miyagi, M., ...Hase, H.: Expression of ACE and ACE2 in individuals with diabetic kidney disease and healthy controls. American Journal of Kidney Diseases, 51, 613-623 (2008)

[43] Wen-lun, H., Yun-yun, Z., Yu, Z., \& Hui-deng, D.: Intrarenal angiotensin II plays an important role in renal fibrosis in primary IgA nephropathy. Biomedical Research, 27(2), 318321 (2016) 